\title{
Penerapan Model Pembelajaran Kooperatif Tipe Make a Match dan Team Games Tournament terhadap Hasil Belajar
}

\author{
Arie Purwa Kusuma1), Ayunitis Khoirunnisa2)
}

1,2 STKIP Kusumanegara, Indonesia

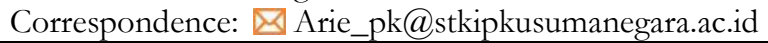

\begin{tabular}{|c|c|}
\hline Article Info & Abstract \\
\hline $\begin{array}{l}\text { Article History } \\
\text { Received : 05-01-2018 }\end{array}$ & This article was conducted to determine whether the results of learning \\
\hline Revised & \\
\hline Accepted : 04-06-2018 & st is done by $\mathrm{r}$ \\
\hline Keywords: & test and homogeneity test. Normality test using Lilliefors test and Homogeneity \\
\hline $\begin{array}{l}\text { experiment; make a match; } \\
\text { TGT. }\end{array}$ & $\begin{array}{l}\text { test using Fisher test. Hypothesis test using t-test. Based on the calculation } \\
\text { concluded the type of Make a Match cooperative learning model and TGT type } \\
\text { cooperative learning model come from the normally distributed population. } \\
\text { Homogeneity test using Fisher test can be concluded cooperative learning model } \\
\text { type Make a Match and cooperative learning model type TGT same or } \\
\text { homogeneous. Based on the hypothesis test, Ho is rejected. In conclusion, the } \\
\text { result of learning mathematics of learners using Make a Match learning model is } \\
\text { better than TGT learning model. }\end{array}$ \\
\hline
\end{tabular}

\section{PENDAHULUAN}

Pendidikan merupakan suatu proses yang didalamnya terkandung banyak aspek yang saling berkaitan dan ketergantungan satu dengan yang lainnya. Selain itu, pendidikan merupakan usaha sadar untuk menyiapkan peserta didik melalui kegiatan bimbingan, pengajaran, dan latihan bagi peranannya di masa yang akan datang [1]. Aspek tersebut terdiri dari tujuan yang hendak dicapai, peserta didik yang belajar, guru yang mengajar, materi yang disampaikan, model yang digunakan, dan evaluasi untuk mengukur keberhasilan kegiatan belajar mengajar tersebut.

Pada hakikatnya belajar merupakan salah satu kegiatan individu dalam usahanya untuk memenuhi kebutuhan. Tujuan dari setiap belajar mengajar adalah untuk memperoleh hasil yang optimal. Kegiatan ini akan tercapai jika peserta didik sebagai subjek terlibat secara aktif baik fisik maupun emosionalnya dalam proses belajar mengajar. Di samping itu, peserta didik ikut berpartisipasi, mencoba dan melakukan sendiri yang sedang dipelajari. Sedangkan dalam pembelajaran yang mengacu dalam pembelajaran aktif. Fungsi guru adalah menciptakan suatu kondisi belajar yang memungkinkan peserta didik berkembang secara optimal. Pembelajaran ini dilakukan agar kelak siswa yang mendapatkan pendidikan dapat bersaing di tingkat lokal, nasional maupun internasional [2].

Dalam Undang-Undang No 20 Tahun 2003 Tentang Sistem pendidikan Nasional disebutkan bahwa pendidikan nasional berfungsi mengembangkan kemampuan dan membentuk watak serta peradaban bangsa yang bermanfaat dalam rangka mencerdaskan kehidupan bangsa, bertujuan untuk perkembangan potensi peserta didik agar menjadi manusia yang beriman dan bertakwa kepada Tuhan Yang Maha Esa, berakhlak mulia, sehat, berilmu, kreatif, mandiri dan menjadi warga negara yang demokrasi serta bertanggung jawab. 
Penggunaan variasi model pembelajaran salah satu hal yang penting di dalam belajar matematika. Peserta didik akan menemukan variasi pengajaran guru di dalam belajar, hal tersebut akan memberikan dampak yang tinggi dan rendahnya hasil belajar peserta didik. Berkaitan dengan hal tersebut kegiatan pembelajaran matematika yang terjadi di kelas VII SMP Bisnis Informatika Bekasi ditemukan adanya masalah rendahnya pengetahuan mengenai materi bangun datar segi empat. 1) kemampuan peserta didik dalam memahami makna bangun datar segi empat (20\%), 2) kemampuan peserta didik menulis rumus bangun datar segi empat (40\%), 3) kemampuan peserta didik memahami makna dari bangun datar segi empat $(18 \%)$, 4) kemampuan peserta didik menulis rumus luas bangun datar segi empat $(22 \%)$. Berdasarkan daftar nilai ulangan harian peserta didik kelas VII SMP Bisnis Informatika, ,masih banyak peserta didik yang mendapat nilai di bawah KKM (Kreteria Ketuntasan Minimum $\geq 65$ ). Hal ini tampak pada setiap ulangan harian yang tidak mengikuti remidi hanya 15 dari 30 peserta didik.

Matematika dipelajari hampir di setiap jenjang pendidikan, baik jenjang sekolah dasar, sekolah menengah, bahkan sekolah kejuruan pun semua mempelajari matematika [3]. Matematika merupakan ilmu penunjang bagi ilmu pengetahuan yang lain [4]. Akar penyebab dari rendahnya hasil pembelajaran pada materi bangun datar segi empat disebabkan oleh beberapa faktor. Faktor- faktor penyebab bisa berasal dari guru, lingkungan, sarana prasarana (strategi pembelajaran) hingga peserta didik itu sendiri. Rendahnya daya serap pada bangun datar ini menandakan bahwa peserta didik masih mengalami kesulitan dalam memahami materi tersebut [5]. Pada kenyataannya proses belajar mengajar yang diciptakan guru di kelas masih kurang baik. Peserta didik diposisikan sebagai pendengar ceramah dari guru. Selain itu pengaruh peserta didik lain yang malas belajar serta sikap peserta didik yang pasif dan kurang berani untuk mengemukakan pendapatnya dalam pembelajaran matematika, karena akan berpengaruh kepada hasil belajarnya. Matematika memiliki peran yang sangat penting karena matematika adalah ilmu dasar yang digunakan secara luas dalam berbagai bidang kehidupan [6]. Model pembelajaran kooperatif merupakan salah satu model pembelajaran yang diterapkan dengan cara berkelompok dan bekerja sama dalam mengonstruksi suatu konsep, menyelesaikan suatu persoalanpersoalan dengan tanya jawab dan diskusi. Ide utama belajar kooperatif adalah siswa bekerja sama untuk belajar dan bertanggung jawab pada kemajuan belajar temannya [7]. Ada beberapa model pembelajaran yang dapat digunakan oleh para guru untuk meningkatkan hasil belajar yaitu model Make a Match dan TGT [7]. Metode Make a Match merupakan salah satu metode pembelajaran kooperatif yang paling sederhana, dan merupakan model yang paling baik untuk permulaan bagi para guru yang baru menggunakan pendekatan kooperatif [7].

Model pembelajaran kooperatif tipe Make a Match merupakan pembelajaran yang melibatkan siswa secara aktif dalam berbagai kegiatan pembelajaran baik secara individu maupun kelompok, sehingga dapat mengembangkan pemahaman dan kemampuan belajar melalui berbuat dan melakukan sama halnya dengan Komalasari, model pembelajaran kooperatif tipe Make a Match adalah model pembelajaran yang mengajak siswa mencari jawaban terhadap suatu pertanyaan atau pasangan dari suatu konsep melalui suatu permainan pasangan.

Model pembelajaran kooperatif tipe Make a Match adalah model yang dimulai dengan teknik, yaitu siswa disuruh mencari pasangan kartu yang merupakan jawaban atau soal sebelum batas waktunya, siswa yang dapat mencocokan kartu maka diberi poin [8]. Salah satu keunggulan teknik ini adalah siswa mencari pasangan sambil belajar mengenai suatu konsep atau topik, dalam suasana yang menyenangkan. Model kooperatif dapat melatih kemandirian dan kerjasama bagi peserta didik [9]. 
Make a Match dikembangkan pertama kali oleh Lorna Curran, model Make a Match menjadi salah satu model yang penting di dalam kelas. Tujuan dari strategi ini antara lain pendalaman materi, penggalian materi, dan edutainment [10]. Dengan model pembelajaran kooperatif tipe Make a Match siswa bisa melakukan pendalaman materi dengan pengetahuannya yang telah siswa miliki kemudian pemahaman tentang materi bertambah dengan pembelajaran yang menyenangkan.

Model pembelajaran TGT adalah salah satu tipe atau model pembelajaran kooperatif yang mudah diterapkan, melibatkan aktivitas seluruh peserta didik tanpa ada perbedaan status, melibatkan peran peserta didik sebagai tutor sebaya dan mengandung unsur permainan dan reinforcement. Aktifitas belajar dengan permainan yang dirancang dalam pembelajaran kooperatif model TGT. Memungkinkan peserta didik dapat belajar lebih rileks di samping menumbuhkan tanggung jawab, kejujuran, kerja sama dan keterlibatan belajar. Belajar secara kooperatif lebih dari sekedar belajar atau kerja kelompok.

Karena dalam pembelajaran kooperatif ada struktur dorongan atau tugas yang bersifat kooperatif sehingga memungkinnya terjadinya interaksi secara terbuka dan hubungan yang efektif di antara anggota kelompok yang lain. Aktivitas belajar dengan permainan yang dirancang dalam pembelajaran kooperatif model TGT sangat mudah untuk diterapkan karena sangat memungkinkan peserta didik dapat belajar lebih rileks di samping menumbuhkan tanggung jawab, kejujuran, kerja sama, persaingan sehat, dan keterlibatan belajar. Saco menyatakan bahwa dalam model pembelajaran TGT peserta didik memainkan permainan dengan anggota-anggota tim lain untuk memperoleh skor bagi tim mereka masing-masing [8]. Pembelajaran yang dikemas dengan suatu permainan memang merupakan salah satu model pembelajaran yang sangat menarik dan bisa menimbulkan aktivitas yang baik bagi peserta didik dalam pembelajaran berkelompok.

TGT adalah salah satu tipe pembelajaran kooperatif yang menempatkan peserta didik dalam kelompok-kelompok belajar yang beranggotakan 5 sampai 6 orang peserta didik yang memiliki kemampuan, jenis kelamin, dan suku atau ras yang berbeda [8]. Dalam pemilihan kelompok yang terdiri dari peserta didik yang memiliki kemampuan yang berbeda ini ditunjukan agar tidak terjadi kecenderungan terhadap peserta didik yang berkemampuan rendah. Setiap peserta didik akan ditempatkan dalam satu kelompok yang terdiri dari 3 orang yang dengan yang berkemampuan rendah, sedang ,dan tinggi. Setiap anggota ditugaskan untuk mempelajari materi terlebih dahulu bersama anggota-anggotanya, barulah mereka diuji secara individual melalui game akademik. Meskipun demikian guru tetap membimbing setiap kelompok jika ada kelompok yang mengalami kesulitan dalam menyelesaikan permasalahan yang ditugaskan. Tujuan penelitian ini adalah mengetahui apakah hasil belajar matematika peserta didik pada materi bangun datar segi empat yang diajarkan menggunakan model pembelajaran Make a Match lebih baik dari pada model pembelajaran TGT. Diharapkan dengan adanya penelitian ini dapat menjadi alternatif solusi dalam pemilihan variansi model pembelajaran yang akan dilaksanakan di kelas.

\section{METODE}

Secara umum model penelitian diartikan sebagai cara ilmiah untuk mendapatkan data dengan tujuan dan kegunaan tertentu [11]. Model yang digunakan yaitu model eksperimen semu (quasi eksperimental design). Populasi dari penelitian ini adalah seluruh kelas VII SMP Bisnis Informatika Bekasi. Penelitian ini dilaksanakan pada Semester dua Tahun Ajaran 2017/2018, teknik pengambilan sampel dalam penelitian ini adalah cluster random sampling sedangkan sampel yang terpilih adalah kelas VII.1 sebagai kelas eksperimen 1, VII.2 sebagai kelas eksperimen 2. Teknik pengumpulan data menggunakan 
model dokumentasi dan model tes. Model dokumentasi digunakan untuk memperoleh kemampuan awal kelas eksperimen 1 dan eksperimen 2. Sedangkan model tes digunakan untuk memperoleh data mengenai hasil belajar siswa kelas eksperimen 1 dan eksperimen 2. Model tes digunakan untuk mengumpulkan data hasil belajar matematika siswa dengan tes berbentuk pilihan ganda sebanyak 30 butir soal untuk tes, tiap butir soal terdiri dari empat pilihan ganda A,B,C,D. Tes diberikan setelah memenuhi validitas soal dan diujicobakan terlebih dahulu di kelas VIII.1 untuk melihat tingkat kesukaran dan daya pembeda butir soal tersebut, serta uji reliabilitas terhadap masing-masing instrumen tes [12].

Sebelum dilakukan uji hipotesis, terlebih dahulu dilakukan uji prasyarat analisis pada kemampuan awal siswa masing-masing kelas yang diambil dari nilai UAS semester ganjil untuk uji keseimbangan dengan taraf signifikansi 0,05 . Uji prasyarat analisis yaitu uji normalitas menggunakan uji Lillifors, uji homogenitas menggunakan uji Fisher, dan uji Hipotesis Statistik menggunakan uji-t [12].

\section{HASIL DAN PEMBAHASAN}

Hasil penelitian menunjukkan bahwa kelompok eksperimen 1 dan kelompok eksperimen 2 berangkat dari kondisi awal yang sama. Setelah diadakan uji normalitas dan uji homogenitas yang menunjukkan bahwa kedua sampel berdistribusi normal dan tidak ada perbedaan variansi. Kemudian dilakukan uji keseimbangan yang menunjukkan bahwa kedua kelompok sampel mempunyai kemampuan awal yang sama. Hasil uji keseimbangan dengan menggunakan uji t dan taraf signifikan $\alpha=$ 0,05 diperoleh nilai uji $\mathrm{t}\left(\mathrm{t}_{\mathrm{obs}}\right)$ sebesar 0,34 dengan nilai tabel $\mathrm{t}_{0.05,58}$ sebesar 1.670 , dengan $\mathrm{DK}=\{\mathrm{t} \mid \mathrm{t}<$ -1.670 atau $t>1.670\}$, sehingga dapat disimpulkan bahwa antara kedua kelompok dalam keadaan seimbang.

Pada kelompok eksperimen 1 yaitu kelas VII.1 dengan jumlah 30 siswa, diberikan perlakuan dengan menggunakan model pembelajaran Make a Match. Sedangkan pada kelompok eksperimen 2, yaitu kelas VII.2 dengan jumlah 30 siswa, diberikan perlakuan dengan menggunakan model pembelajaran TGT. Setelah masing-masing kelas diberi perlakuan dengan model pembelajaran yang berbeda, keduanya diberi tes hasil belajar matematika.

Tes hasil belajar matematika tersebut, sebelumnya telah diujicobakan di kelas lain yaitu kelas VIII.1. Kemudian dilakukan uji validitas item, tingkat kesukaran, daya pembeda dan uji reliabilitas, sehingga diperoleh bahwa tes tersebut reliabel dan item soal yang digunakan memenuhi validitas item. Hasil dari tes hasil belajar matematika kedua kelompok dilakukan uji normalitas, uji homogenitas dan uji hipotesis. Berdasarkan hasil penelitian uji normalitas didapat perhitungan diperoleh data bahwa hasil uji Lilliefors model pembelajaran kooperatif tipe Make a Match $\mathrm{L}_{\text {hitung }}<\mathrm{L}_{\text {tabel }}(0,1380<0,1610)$ dan untuk model pembelajaran kooperatif tipe TGT $\mathrm{L}_{\text {hitung }}<\mathrm{L}_{\text {tabel }}(0,1485<0,1610)$, sehingga dapat disimpulkan model pembelajaran kooperatif tipe Make a Match dan model pembelajaran kooperatif tipe TGT berasal dari populasi yang berdistribusi normal. Uji homogenitas menggunakan uji Fisher diperoleh $\mathrm{F}_{\text {hitung }}$ $<\mathrm{F}_{\text {tahel }}(1,026<1,85)$ sehingga dapat disimpulkan model pembelajaran kooperatif tipe Make a Match dan model pembelajaran kooperatif tipe TGT sama atau homogen. Berdasarkan uji hipotesis menggunakan uji $\mathrm{t}$ diperoleh $\mathrm{t}_{\text {hitung }}>\mathrm{t}_{\text {tabel }}(2,12>1,67)$, maka Ho ditolak.

Dilihat dari rataan marginalnya, rerata hasil belajar matematika yang menggunakan Model Pembelajaran Make a Match diperoleh 76,9, sedangkan rerata hasil belajar matematika yang 
menggunakan model pembelajaran TGT 74.2. Tampak bahwa rerata hasil belajar matematika siswa dengan Model Pembelajaran Make a Match lebih tinggi daripada rerata hasil belajar matematika yang menggunakan model pembelajaran TGT. Jadi dapat disimpulkan bahwa Model Pembelajaran Make a Match menghasilkan hasil belajar matematika siswa yang lebih baik daripada model pembelajaran TGT pada kelas VII SMP Bisnis Informatika Bekasi pada semester genap tahun pelajaran 2017/2018 Hal ini sesuai dengan hipotesis teori.

\section{SIMPULAN DAN SARAN}

Simpulan dari penelitian ini adalah hasil belajar dengan menggunakan model pembelajaran kooperatif tipe Make a Match memberikan hasil belajar matematika yang lebih baik dibandingkan model pembelajaran kooperatif tipe TGT pada materi bangun datar segiempat di kelas VII SMP Bisnis Informatika Bekasi. Semester II tahun ajaran 2017/2018. Berdasarkan hasil penelitian didapat beberapa hal yang perlu diperhatikan yaitu keterlibatan peserta didik lebih aktif dalam proses belajar mengajar yang akan meningkatkan hasil belajar bagi peserta didik itu sendiri. Peran yang sangat penting bagi guru dalam proses belajar mengajar maka sebaiknya guru memahami berbagai macam model atau metode belajar dan mempersiapkan secara maksimal setiap metode yang akan dipergunakan baik penguasaan materi, peralatan mengajar, alat peraga dan faktor yang akan mempengaruhi hasil belajar agar hasilnya lebih maksimal.

\section{DAFTAR PUSTAKA}

[1] A. D. Susandi and S. Widyawati, "Proses Berpikir dalam Memecahkan Masalah Logika Matematika Ditinjau dari Gaya Kognitif Field Independent dan Field Dependent," Numer. J. Mat. Dan Pendidik. Mat., p. 93, Jul. 2017.

[2] S. Ahmad, M. Kristiawan, T. Tobari, and S. Suhono, "Desain Pembelajaran SMA Plus Negeri 2 Banyuasin III Berbasis Karakter Di Era Masyarakat Ekonomi ASEAN," Iqra J. Kaji. Ilmu Pendidik., vol. 2, no. 2, pp. 403-432, Dec. 2017.

[3] C. Zahra, S. Widyawati, and E. F. Ningsih, "Eksperimentasi Model Pembelajaran Kooperatif Tipe Student Facilitator And Explaining (SFE) Berbantuan Alat Peraga Kotak Imajinasi Ditinjau Dari Kecerdasan Spasial," JIPMat, vol. 2, no. 2, Dec. 2017.

[4] E. F. Ningsih, M. Mardiyana, and G. Iswahyudi, "Eksperimentasi Model Pembelajaran Kooperatif Tipe Team Assisted Individualization (Tai) Dengan Metode Snowball Drilling Terhadap Prestasi Belajar Matematika Ditinjau Dari Kemandirian Belajar," J. Pembelajaran Mat., vol. 2, no. 7, Sep. 2014.

[5] S. Widyawati, "Eksperimentasi Model Pembelajaran Kooperatif Tipe Two Stay Two Stray (TSTS) Dan Numbered Heads Together (NHT) Ditinjau Dari Kecerdasan Majemuk Peserta Didik,” p. 12, 2014.

[6] L. S. Wahyuniar and S. Widyawati, "Proses Berpikir Mahasiswa Dalam Menyelesaikan Soal Kombinatorial Berdasarkan Kecerdasan Logis Matematis," vol. 1, no. 2, p. 27, 2017.

[7] R. E. Slavin, Cooperative Learning: Teori, Aplikasi dan Praktek. Cetakan kedelapan. Bandung: Nusa Media, 2010.

[8] Rusman, Model-model Pembelajaran. Depok: Raja Grafindo Persada, 2012. 
Numerical: Jurnal Matematika dan Pendidikan Matematika, Vol. 2 No. 1 Juni 2018, 1-6

Arie Purwa Kusuma, Ayunitis Khoirunnisa

[9] M. Kuslaila, E. F. Ningsih, and W. Kusumaningtyas, "Eksperimentasi Model Pembelajaran Pair Checks Pada Materi Pokok Segitiga Ditinjau Dari Gaya Belajar Peserta Didik," JIPMat, vol. 2, no. 2, Dec. 2017.

[10] L. Curran, Cooperative learning lessons for little ones: Literature-based language arts and social skills. Resources for Teachers, Incorporated, 1991.

[11] M. Sugiyono, Metodologi penelitian pendidikan. Jakarta: Rineka Cipta, 2011.

[12] Budiyono, Statistika Dasar Untuk Penelitian. Surakarta: UNS Press, 2013. 